\title{
The Preference for English in Digital Media among Indonesian Millennials
}

\author{
Ignatius Harjanto \\ harjanto@ukwms.ac.id \\ English Education Department, \\ Faculty of Teacher Education, \\ Widya Mandala Catholic University Surabaya, \\ Surabaya, Indonesia
}

\section{Article History \\ Received: 17-04-21 \\ Reviewed: 15-05-21 \\ Accepted: 25-05-21}

Keywords: language use; identity; language preference; social media

DOI:

https://doi.org/10.33508/bw.v9i1.3143

\begin{abstract}
The use of English among Indonesian millennials has been more widespread especially because of exposure to English has been so massive to secondary school in urban areas. There has been a concern that the increasing use of English might diminish their Indonesian language use and cultural identity. This study aims to investigate the roles of English on satellite TV programs and social media posts for Indonesian millennials, their language preference, and the consequences of language preference on their national identity. A concurrent embedded mixed methods design collecting quantitative and qualitative data was carried out through short essays and closedquestionnaires. Both questions of essay writing and closedquestionnaires were sent to students of private high schools in two big cities (Jakarta and Surabaya), aged 18 to 20 years old online. The questionnaire items were in multiple-choice and the short paragraph essay explained the importance of TV programs and social media posts for learning English. After being scrutinized, 989 respondents' essay responses were analysed. The findings showed that TV programs and social media posts were claimed to have important roles of English learning resources. Although they practiced English through social media, they felt that they still kept themselves as Indonesians when using English on social media
\end{abstract}

\section{Introduction}

The world is now characterized with rapid flow of information, capital, and services that are unprecedentedly changing how and where people connect, collect and share information, and use the media. The present world changes very rapidly because of technology. Technology advancement in satellite television (TV) and social media has not only disrupted industries and business models but it may also change language and identity of Indonesian millennials. Various news, lifestyles, and entertainments all over the world are introduced to Indonesian millennials on TV. With the internet connection, Indonesian millennials can accept, post and share diverse video contents on the web with YouTube through social media applications. All these enable Indonesian millennials already have the world and its information in their palms. Surely, their life and experiences significantly different from the previous young Indonesians.

Couch potatoes have been widely known to have negative effects on overall physical activity levels. However, wise use of 
programs on TV could be the factor of language change. Stuart-Smith, Timmins, Pryce, \& Gunter (2013) suspected that the language of television viewers were influenced by their favourite TV drama. Several factors that contribute to language change could be related to dialect contact between the language of TV viewers and the language used by the actors or actresses on TV drama. It was believed that a drama on TV disseminate the language spoken by the actors to TV viewers.

Similar with TV usage, prolonged and uncontrolled use of social media could result in learning and mental health problems, and academic achievement. Abbas, Aman, Nurunnabi, \& Bano (2019) found that social media affected negative student's learning. Hou, Xiong, Jiang, Song, \& Wang (2019) found that self-esteem intervention could reduce social media addiction and improve mental health and academic performance. To improve academic performance, students should understand the negative sides of social media use and increase self-esteem. Different from the previous studies, Elbadawy \& Hashem (2015) argued that social media did not affect academic performance. The studies on the usage of social media reviewed dealt with mental health and academic performance, not with language preference.

YouTube shared through social media disseminates language effectively. In the world of education, students and teachers benefit from YouTube as a multimedia education prepared to teach, compiled resources for student homework. Different from traditional education which heavily depends on the teacher-sole-expert model, the now education facilitates students to access YouTube providing useful sources of authentic language input areas where nativespeaker teachers are not available. Further, the application of YouTube in the EFL teaching supports the students English speaking development (Alkathiri, 2019).

English which has been widely used in education, business, career, and modern life is boosted by social media users. According to Murray \& Christison (2019) English is the main language of social media among nonEnglish speakers; English is the lingua franca of online social media. Khan, Ayaz, \& Faheem (2016) reviewed that students' vocabulary English was well improved through social media. Arndt \& Woore (2018) found that non-English students acquired vocabulary by reading blog posts and watching vlogs. In line with this issue, LantzAndersson (2018) opined that English is used "a means for various socializing purposes ( $p$. 705).”

English and social media tend to have close relationship. Ali \& Hasanabbasi (2015) reviewed that social media play a very important role in providing authentic materials that students of English as a second language can benefit from. In the same way, Indonesian millennial students can learn English from native speakers of English via different platforms used in social media. Through social media, YouTube is good for language and intercultural learning resource (Benson, 2015).

In addition to English learning resource, social media enable users to keep relationships. Kommers (2011) stated that one of the two most visible applications of social media is to build and consolidate friendship among users. They can develop a community where the users share their understandings and experiences on a particular issue. Such a community practice (Wenger, 2010), according to Kommers (2011), is social constructivism where web users come up with their own questions, create their own theories, and examine them 
for feasibility. According to Anderson (2006), the key element of community formation is the development of a common language.

Online communication affects on the language of the users. Social networking enable the users to construct their profile within their online community which may reflect their identities. Gervasio \& Karuri
(2019) found that social media users mark their identity through language. It is argued in this study that Indonesian millennials using social media can form a community with English as the common language among them (Murray \& Christison, 2019; LantzAndersson 2018; Khan, Ayaz, \& Faheem, 2016) and may construct new identity.

\section{Theoretical Framework}

Language learning requires students to experience cognitively, physically, and emotionally (Sa'd, 2017). Foreign students learning English experience in using their own first language and English as a foreign language (EFL). When learning an EFL, they are conscious of themselves as students of an EFL and their own identity. Students learning a foreign language are characterized both by who they belong to and who they don't (Norton \& Toohey, 2011). If EFL students do not recognize themselves in the target community, they will not maximally participate in learning English. EFL students do not only learn linguistic items but also social and cultural aspects. Indeed, language competence is not limited to linguistic knowledge but also social and cultural understanding. Speaking the target language, EFL students assign and reassign their identities. Accordingly, identity construction is an ongoing, continuous, and dynamic process of language use (Larsen-Freeman \& Cameron, 2007) with distinct stages (Rassokha, 2010).

Language learning and identity construction are closely related (Norton \& Toohey, 2011; Abrar-ul-Hassan, (2010). Reviewing previous studies, Yazan, Rudolph, \& Selvi (2019) identified that language learners undergo a process of identity formation of which interaction among language, culture, space, and identity are not clearly cut. Learning a new language
(English) enables students to form a new identity (Lightbown \& Spada, 2006; Pavlenko \& Lantolf, 2000). It is believed that language learning and identity formation are complementary. It is understood that identity formation can be realized through the use of native language or foreign language.

Lie, Wijaya, \& Kuntjara (2018) found that language played a central role in the development and expression of identity. They argued that language is the identity markers that can construct speakers' social identity. Language is the most immediate and universal symbol of identity (Crystal, 2011). English learners undergo different changes in their cultural identity, shifting from little or almost no change to accept new identity formation. They are confronted with their understanding about their native language and culture and their awareness of learning English. Reviewing previous argument about identity, Zhou \& Zhou (2018) mentioned that language learners "had to solve certain identity struggle and conflicts" (p. 1).

Bilingual speakers experience native and foreign identity. Lambert (1974) identified two types of bilingualism, they are additive and subtractive. Additive bilingualism refers to language learners who maintain their native language and cultural identities when they acquire the target language and cultures. Subtractive bilingualism happens when learners' native language and cultural identity are substituted 
by the target language and culture. Further, Gao (2002) recommended productive bilingualism referring to language learners whose native language and culture support each other with the target language and culture positively. Productive bilingualism is the most ideal one. Turnbull's findings (2017) suggest that EFL learning in Japan should be positioned in the development of both the students' English and Japanese.

Other changes in self-identity by Gao, Zhao, Cheng, \& Zhou (2007) were categorized into six: self-confidence, productive, additive, subtractive, split, and zero. They argued that self-confidence is a "prerequisite" for successful bilingualism. Split bilingual, which was a transitional stage, takes place when learners felt contradiction and conflicts between their native language/culture and the target ones. Gao, Jia, \& Zhou (2015), studying 4-year longitudinal study, found that Chinese students learning EFL in in their home setting underwent prominent identity changes. Of the six identity changes, positive self-confidence change was the most prevalent. The longer the students learned English the higher changes were experienced. They reported that Chinese learners increased additive, productive, and split changes in the fourth year of EFL learning. Changes in subtractive started low but went through a steady increase.

Social and demographic factors affect the formation of language identity. Abrar-ulHassan (2010) found that students' social identity is the manifestation of their language identity. Other studies reviewed by Murray \& Christison (2019) showed that English students from different places underwent self-language identity formation. Further, students' self-language identity changes affect the role of non-English teachers.
Motivation is important in language learning; unfortunately, the psychological construct of motivation itself does not clearly explain how a language learner is highly motivated in learning the target language ( Norton, 1995). Norton (2013) argued that language investment is crucial in the achievement of language acquisition. According to her, a language learner may be highly motivated but has small investment in the target language. Investing a language helps learners acquire the target language resources increasing the value of their cultural capital and social power. Accordingly, a language learner may have high motivation but low investment in language; on the other side, a learner who invests in a certain set of language practices will likely be motivated in learning the language.

Digital technology is an investment that is inevitable in the $21^{\text {st }}$ century. Digital technology has a significant role in transforming language learning and identity. Darvin \& Norton (2015) opined that technology has "radically transformed language by triggering an explosion of new vocabularies, genres, and styles, and by reshaping both the meaning and practice of literacy" ( $p, 23)$. Digital technology does not only enable the production of new words and styles but also "multilingual encounters and translingual practices, revitalizing languages and asserting new identities" (Darvin, 2016 p. 536).

Schreiber (2015) found that EFL learners experienced translingual written practices on the digital media. As an implication of her findings, she suggested English teachers to reconsider the meaning of EFL-mediated identity and to develop the focus of EFL writing instruction. LantzAndersson (2018) found that the social media facilitated students to practice casual 
communication in English as L2. She argued that social media enabled the students to develop their daily sociopragmatic competence not found in the English class.

Research on the role of social media on language education has been a growing interest lately. Reviewing social media used to develop language learning out of the class, Ali \& Hasanabbasi (2015) concluded that social media are beneficial media to English learning. This could be realized because social media communicate meanings in a variety of forms such as text, music, sound, and images (Norton \& Toohey, 2011). Akbari, Naderi, Simons, \& Pilot (2016) reported that English learners benefited from Facebook; their engagement and motivation in learning English were higher than those who learned English face to face. Anankulladetch (2017) found that English students who received social media intervention demonstrated greater perception of engagement and improved upon their learning performance more than those who did not receive the social media intervention.

Besides developing language learning, social media facilitates the development of intercultural competence (Izmaylova, 2017). She found that Facebook is uniquely suitable for a tele-collaboration; students had an opportunity to develop their own accessible language learning environment. It is argued that Facebook is a platform which could be effective for foreign language instruction. Based on the results of her study, Jin (2015) also suggested to use Facebook to teach intercultural interactions in the EFL classroom because it was practical to accommodate intercultural interactions between EFL students and native speakers of English.

It was widely known that literacy skills are developed from popular communication media such as newspaper, magazine, radio, and television. Traditional literacy which was regarded as a set of skills such as reading, writing, and arithmetic could be enhanced from the mainstream communication channels. With the development of information and communications technology, however, the scope of literacy changes accordingly. The changes of new technologies and the social practices have led to "New Literacy" which develops from Internet-based media such as Web, Twitter, blogs, YouTube, Facebook, mobile technologies (Simsek \& Simsek, 2013 p. 126).

"New Literacy" is different from traditional literacy which regarded literacy as a mental phenomenon considering reading and writing as activities inside people's head. "New Literacy" is real and is practiced in social and cultural group within digital media environments comprising the $21^{\text {st }}$ century skills (Spires, Morris, \& Zhang, 2012). "New Literacy" is beyond print literacy; it is digital literacy which requires skills specific to a certain technology.

Digital literacy and identity are interdependent so that students' access to a variety of literacy can affect their identity. Digital spaces allow opportunities for selfexpressions which may reveal their identity. Identity in the digital territory is perceived as a literacy concept that enables users to express themselves freely carrying out their self-concepts and values (Simsek \& Simsek, 2013). Self-expressions on digital media may assert digital media users to negotiate their identity.

Zhao, Grasmuck, \& Martin (2008) reported that Face bookers' identities were formed implicitly rather than explicitly; they showed rather than told their identities. In line with language identity, Rezaei \& Latifi (2019) found that the Iranian EFL learners' awareness of the intercultural and interlingual issues were moderate; they were 
aware of Persian as their national language while English is their foreign language.

Eager to know digital media as language learning resources, this study investigated (1) the roles of satellite TV and social media (i.e., YouTube, Instagram, Facebook) for Indonesian post-millennials, (2) their language preference, and (3) the consequences of language preference on their identity.

\section{Research Method}

This study is a concurrent embedded mixed methods design (Creswell, 2014) collecting quantitative and qualitative data on the topic of language use on digital media in in the same time. The data were collected from high school students. The data of this study were taken through short essays and closed-questionnaires. In this study, the primary method used was short essays written by the respondents. Authentic opinions about digital media, language preference and effects of language preference on the respondents' identity were taken with free writing in English. These opinions were elaborated with quantitative data taken with closed-questionnaires. Information about digital media, language preference were addressed through closedquestions questionnaire items. Although the primary data was qualitative, the presentation of the findings was started with quantitative data and completed with qualitative data. The primary data of written opinions were used to dig deep the responses of the closedquestionnaires. Besides being used as opinions for their English preference, the short essays in English were taken as evidence for their English proficiency. Integrating quantitative and qualitative data were done to answer the research questions.

The participants of this study were millennials recruited using purposive random sampling (Ary, Jacobs, \& Sorensen, 2010) from private schools in two big cities: Jakarta and Surabaya. They were selected because they, i.e., their family, subscribed TV cable channels and used social media in their daily lives. The participants emphasizing lifestyle and experience (Kementerian Keuangan Republik Indonesia, 2019) belonged to middle class families who could access satellite TV cable channels and afford smartphones as their lifestyles. They changed their needs to their wants; attractiveness, beautifulness and the like were attached to their daily appearances. Although they were students, they loved fashion, enjoyed performing arts and tourism. This could be traced from their social status on their social media accounts. Overall, the participants were homogeneous having similar socio-economic background, level of education, hobby, and age.

Both questions of essay writing and closed-questionnaires were sent to the respondents online. One short instruction asking the participants to write a short essay of 100 to 150 words explaining the importance of $\mathrm{TV}$ and social media for learning English was addressed. The closedquestionnaire items required the participants to choose one correct answer of multiplechoice questions about the use of digital media including TV, YouTube, and social media. Including in the social media were YouTube, Instagram, Facebook. The other items asked the participants to choose their language preference used on social media postings and the practices with social media postings and effects of language preference on their identity.

There were 989 returned questionnaires taken as the data source of this study. These returned questionnaires were scrutinized based on the contents of the short essays. Written short essays having same (copy

BEYOND WORDS Vol. 9, No.1, May 2021 Graduate School, Widya Mandala Catholic University Surabaya 
paste) and similar in content were considered as being redundant and put aside. Indeed, participants who did not write a short essay or whose essays were unintelligible essays were dropped.

\section{The Roles of TV and Social Media for Indonesian Millennials}

Indonesian and overseas TV cable channels, as the mainstream media, were still the main forms for entertainment and news. Table 1 reports that entertainment was dominant over news. The interesting entertainment programs for Indonesian student millennials (i.e., participants) were movies, TV shows, sports, and music.

Almost all participants from Surabaya preferred to watch entertainment programs on TV. The percentage of the participants from Jakarta having similar preference was a bit lower than those from Surabaya. Whenever the participants were in front of TV, they switched on entertainment programs; news programs such as lifestyle and current news were sometimes chosen.

Table 1.

\section{TV as the Main Stream Media for}

\section{Indonesian}

Millennials

\begin{tabular}{lrclr}
\hline \multirow{2}{*}{ Television } & \multicolumn{2}{c}{ Entertainment } & \multicolumn{2}{c}{ News } \\
\cline { 2 - 5 } Cities & $\mathrm{N}$ & $\%$ & $\mathrm{~N}$ & $\%$ \\
\hline Surabaya & 727 & 94 & 44 & 6 \\
\hline Jakarta & 184 & 84 & 34 & 16 \\
\hline
\end{tabular}

Two main languages, Indonesian and English, were on Indonesian TV programs. In Indonesian TV programs, news, entertainments, and advertisements were in Indonesian; however, movies and music were either in Indonesian or English. TV cables provided both Indonesian and English programs; overseas TV cable programs mostly watched by the participants were the ones in English. As shown in Table 2, the participants of this study preferred to watch TV programs in English than those in Bahasa
Indonesia. More than three quarters of the total numbers of the participants $(80 \%$ participants from Jakarta and 79\% from Surabaya) chose TV programs in English because of the contents and language. They watched movies in English not in Indonesian because the stories were sophisticated, interesting, and inspiring. They thought that the stories of TV movies in Indonesian could be guessed and monotonous. Indeed, TV movies in English were sources of English learning. Watching movies in English familiarized them with English pronunciations and expressions.

\section{Table 2.}

Language Preference on TV

\begin{tabular}{lcccc}
\hline Language & \multicolumn{2}{c}{ English } & \multicolumn{2}{c}{ Indonesian } \\
\hline Cities & $\mathrm{N}$ & $\%$ & $\mathrm{~N}$ & $\%$ \\
\hline Surabaya & 609 & 79 & 162 & 21 \\
\hline Jakarta & 174 & 80 & 44 & 20 \\
\hline
\end{tabular}

Opining in written about the importance of electronic and social media, the participants considered English as the language of the media industry that can be a learning sources. They learned English from TV shows, movies or music. They stated that they experienced in improving their English skills and language elements.

... Children nowadays speak English fluently... because they get used to watching $t v, \ldots$ (J_ASAA-33).

We can watch YouTube and TV shows to improve our speaking and listening skills, and we can also read articles in English to practice our writing and reading skills (S_JAW-17).

The learning strategies applied to improve their English when learning from TV programs were listening to TV programs 
and using subtitles. I usually watch movies or videos ... using English subtitles ... it helps me a lot to improve my vocabulary, hearing, and grammar (Sby_VAS-33). Listening attentively to TV cable shows and movies improved their speaking skills. Reading subtitles on the screen helped them to improve their speaking, listening, vocabulary, and grammar. When reading subtitles, they probably matched with expressions, phrases, words spoken on the TV shows or movies. The other participants, however, preferred to learn English from TV movies without subtitles. ... I prefer learning English ... watching movie without subtitle.... (F_JKT-48).

In summary, TV had been an important role for the participants of this study as both media of entertainment and learning. The interesting TV shows and movies in English triggered the participants to learn English. Some participants benefited from subtitles to improve their English, the rest ignored subtitles but listened to and watched TV shows and movies as an effective way to improve their English.

The participants of this study were very familiar with social media. Most of them claimed that social media was a lifestyle, a part of their daily lives. Social media has become a lifestyle for the community and is often used daily (S_SON-4). There was an indication that they were addicted to social media and its applications because of their benefits and functions. They recognized that they lived in the era of technology and used social media to communicate globally with others far away from them, access new information, keep the latest news, and learn English.

Social Media is very important because if we follow the foreign accounts, the posts will mostly be in English. It automatically helps us to learn English. Because we will learn new words. And we can see the correct grammar (J_ITD-199).

The participants of this study used social media everywhere: home, school and community.

They kept communicating with other people and learning English with social media. At home, they used social media keep communicating with their family members, parents and siblings, when they were physically away. When communicating with their family members using social media, they also practiced English. At school, social media was used as a tool for learning English in group or pairs and communicating with teachers and friends. The participants could find English words, grammars, and articles from social media posts. In the society, social media was a popular means of communication and socialisation among users in English that enabled them to learn English. Inevitably, they used social media for several reasons but learning English was the main one.

At home, social media could help parents and children to learn and communicate better English... at school, students can learn English by listening others speak English, reading articles and books in English, watching educational videos about English, and etc. ... in social communities, social media could help others to learn, study, and even speak English with others.... better (S_ER-4)

Through social media, the participants could access authentic English by native speakers. English is such a difficult language to learn for a non-native speakers, but with social media, the participants could learn an

authentic English spoken by English native speakers. The native speakers did not only expose authentic English but also helped to find proper learning resources. Such meaningful and interesting materials 
made the participants more engaged and motivated to learn English. Different from English books, social media exposed the participants to English as it is spoken in the real world. Social media makes me closer to people from around the world, including native English speakers. With the social media I can chat with them easily, learn English, and learn their accents (M_NSP371).

Social media were taken as a practical and flexible distant communication device which allows them to keep informed and friendship. The participant in Jakarta wrote as follows:

I learn how to speak and use English mostly from informal education, YouTube, games, and interacting with friends, ... I think social media is a very good media for learning English whether at school, home, or the social community itself. Medias like this are much more flexible at indirectly teaching English to students .... (J_BJ-17).

Social media enabled the family and friends of the participants to keep contacting although they were separated with distances; even they could manage their future family gatherings.

Although social media were mostly popular because of its benefits for the participants to communicate, keep friendship, learn and enhance English, some negative sides were also recognized. The advantage is we can have many friends from ... abroad, as a medium of learning a foreign language ... The disadvantage is when we abuse it like a bad friend and open an adult site (M_CVK-9). They thought that users of social media should not abuse social media but be wise, able to manage their time well, and considered the bad effects. This was due to the rising number of wrongdoings and offenses against the use of social media such as sending hoax news, hate speech and identity forgery, and commenting stupid viral things. The negative effects of social media use was not related to the function of social media as an English learning resource. Social Media doesn't give a very good effect on the community. Many people abuse it. Many Indonesian people didn't realize how those "things" in it is actually useless (M_CG-6).

\section{Language Preference}

Many social media platforms are available and used. However, YouTube seemed to be the most popular social media websites for the participants. More than just a video-sharing platform for entertainments, YouTube was also a popular video-sharing platform for learning English. The participants thought that YouTube provided them entertainments, information, and even education. Through YouTube, they could learn virtually any knowledge, skills, and English. The survey showed that they preferred to watch TV programs and videos in English. Table 3a and $3 \mathrm{~b}$ display the language preference of the participants. Both tables show that a very high percentage of the participants preferred TV programs and video clips in English. TV programs and video clips in English were very popular for both participants in Jakarta (79.72\% and 90\%) and Surabaya (79.09 \& $84 \%)$. On the other hand, TV programs and video clips in Indonesian were of little interest to be enjoyed and watched by the participants in Jakarta (20.28 \& 10\%) and Surabaya (20.29\% \& 16\%). Accordingly, TV programs and videos YouTube in English were much more trendy among participants than those in Indonesian.

\section{Table 3a.}

\section{Language Preference on TV Programs}

\begin{tabular}{l|c|c|c|c}
\hline \multirow{2}{*}{ Languages } & \multicolumn{2}{|c|}{ English } & \multicolumn{2}{c}{ Indonesian } \\
\cline { 2 - 5 } Cities & $\mathrm{N}$ & $\%$ & $\mathrm{~N}$ & $\%$ \\
\hline Surabaya & 610 & 79.02 & 162 & 20.98 \\
\hline Jakarta & 173 & 79.72 & 44 & 20.28 \\
\hline
\end{tabular}


Table 3b.

Language Preference on Social Media

\begin{tabular}{lcccc}
\hline \multirow{2}{*}{ Language } & \multicolumn{2}{c}{ English } & \multicolumn{2}{c}{ Indonesian } \\
\cline { 2 - 5 } Cities & $\mathrm{N}$ & $\%$ & $\mathrm{~N}$ & $\%$ \\
\hline Surabaya & 646 & 84 & 125 & 16 \\
\hline Jakarta & 196 & 90 & 22 & 10 \\
\hline
\end{tabular}

Video clips commonly accessed through YouTube and TV shows watched were in English. Video clips on YouTube helped the participants to improve their English: language skills and components. Besides video clips or movies, other social media platforms provided the participants sources to learn English anywhere and anytime. The following are some of their comments.

We can watch YouTube and TV shows to improve our speaking and listening skills, and we can also read articles in English to practice our writing and reading skills (S_JAW-17).

We can watch YouTube and TV shows to improve our speaking and listening skills, and we can also read articles in English to practice our writing and reading skills (S_CJ-18).

... English on social media ... helps us to learn English deeper by watching videos in English on YouTube, listening to English music... (S_AID-44).

Social media has become one of the media that exposes people with English usage. With the usage of social media, we are subconsciously slowly learning English phrases and terms (M_MKE-382).

Social media is one of the easiest way to learn English. It is because by using media like YouTube, Instagram, etc. everyone can hear English or read English. This is a good way to be used at the language English. Well this is actually one of the way I understand English by being exposed to it at a daily basis (J_CA-179).
They learned English from social media platforms by watching, listening, chatting; even, they could prepare themselves for English test. One of the participants wrote "... we (I) can search on YouTube to learn grammar or how to write correctly, etc. We (I) can also search about IELTS test on YouTube" (S_CLS_30).

The participants of this study tended to received social media posts more in English than those in Indonesian. Here in Indonesia you can choose between English and Bahasa Indonesia. Well, I and some of my friends prefer to choose English to Indonesia (J_JAK-47). The other participants said, I love using English, its more universal than Bahasa I think, I can easily communicate with people around the world by using social media (J_LSAW-76). Supporting the preference for English on social media, the participant wrote social media is a global media that English is mostly used.

Table 4 shows that more than a half number (630) of the whole participants (989) accepted social media posts in English from the original posters (OP). The participants from Surabaya who received posts in English were higher in percentage $(66 \%)$ than those from Jakarta (57\%). Although Surabaya is smaller than Jakarta, the participants from Surabaya got higher English exposers than those from Jakarta. The original posts in English could be about messages, news, games, songs, stories, videos, or captions. These posts were mostly from overseas posters/leaders. Social media is important to learn English because it contains a lot of English content, such as overseas celebrity, famous influencer, and many more (S_VE_79). The other participant wrote, At line or Instagram, I often see or follow western people that of course use English every time they post something (J_AJ-7) 
Table 4.

Social Media Posts Accepted by the Participants

\begin{tabular}{lcccr}
\hline \multirow{2}{*}{ Languages } & \multirow{2}{*}{ English } & \multicolumn{2}{c}{ Indonesian } \\
\cline { 2 - 5 } Cities & $\mathrm{N}$ & $\%$ & $\mathrm{~N}$ & $\%$ \\
\hline Surabaya & 506 & 66 & 265 & 34 \\
\hline Jakarta & 124 & 57 & 94 & 43 \\
\hline
\end{tabular}

Receptive English learning from social media posts was first done. Reading social media posts in English led the participants to learn, exercise about English, and see the world. They got used to watching videos in English. Social media is already a part of our life in this modern era. We can use this to learn English by reading text messages, watching videos, etc. (J_NMT-133). Social media enabled them to do independent English learning; they made English learning groups with heterogenous members that made them to learn each other about English easily. "In my opinion learning English ... in social media is very important ... we usually create a group at social media to learn English with the other people or our friends .... So, learning English in social media is very important!" (J FES-119). One of the respondents affirmed the benefits of social media as a learning resource.

Personally I think that social media is not only a platform where you can socialize online with people from all over the world, but it's also a great platform to learn English since probably most social media users use English and posts in English, and therefore we must adapt to understand the English language in order to understand these users, and we can use social media to learn English anywhere, as long as it is appropriate, such as home, school, or community (J_MBA_38).

They were assured that the English rules they learned were correct because of English native speakers' posts. With social media I can learn vocabularies, grammars, words, and correct sentences to improve my English (S_WN-31). Further, with correct English rules acquired, they could improve others' English in the group. In short, English social media posts assisted the participants to learn and enhance reading skill, vocabulary, and grammar.

The participants of the study posted contents in English more than the ones in Indonesian. Table 5 indicates that very high posts numbers (840) were in English. The number of their posts in English were much higher (Surabaya 86\% and Jakarta 80\%) than their posts in Indonesian (Surabaya 14\% and Jakarta 20\%). The participants from Surabaya posted contents in English slightly higher than the participants from Jakarta. Comparing data in Table 4 and Table 5, the findings showed that the participants who dealt with productive English, in Jakarta (80\%) and Surabaya (86\%), were much higher than receptive English, in Jakarta $(57 \%)$ and Surabaya (66\%).

There was a tendency that the participant wrote in English posts higher than those read English posts. Of the reasons they posted in English was as follows. If you post something in English, it can be understood by most of the country.... (J_ADP-51). Posting in En-glish may improve their English, Social media usually helps us to improve our English proficiency. Because we can com-municate with other people in English and see other people posts in English (S_NT-8).

Table 5.

Language Preference for Social Media Posts by participants

\begin{tabular}{lllll}
\hline \multirow{2}{*}{$\begin{array}{l}\text { Languages } \\
\text { Cities }\end{array}$} & \multicolumn{3}{c}{ English } & \multicolumn{2}{c}{ Indonesian } \\
\cline { 2 - 5 } & $\mathrm{N}$ & $\%$ & $\mathrm{~N}$ & $\%$ \\
\hline Surabaya & 666 & 86 & 105 & 14 \\
\hline Jakarta & 174 & 80 & 44 & 20 \\
\hline
\end{tabular}


Realising English as a global language, the participants of this study were encouraged not only to learn English but also practice English on social media. Social media did not only provide English exposers but also a forum for practising English. Social Media can be used to learn. Example, I watch the vlogs from YouTube, mostly vlogs are using English for the language speaking. From that vlog, I heard English, .... (J_LL193). Using English for communication was done in a sequential process, they stepped from receptive language skills and then stepped in learning productive skills. Listening was one step many participants point to as an integral step in learning to write social media posts.

With social media, my listening could be improved very much by hearing other's talk in social media apps and also hear some music from other countries. And also it could improve my writing by commenting at other's post (J_MT-6). They did not only read social media posts but also posted contents in English.

Higher percentages both in writing and reading strongly indicated the use of social media as a medium of English learning. Even, they suggested schools to use social media as the media of English learning to

The usage of English on social media was done consciously. One of the participants explicitly wrote:

Most of us will at least spend a total of 4 hours at home scrolling down our social media, trying to write a good English status/caption, listening to music/ videos in English, and reading some articles written in English. (M_MA-21).

The main purpose of choosing English on social media posts was to learn English and broaden their insights. This does not mean that the usage of Indonesian was totally neglected. They still read or wrote social make English subject interesting. One of the respondents shared his feeling,

"Sometimes I prefer to learn English from the internet and social media than to learn at school because Ifeel that if I just rely on the skills that I got at school is not enough. Because in my opinion, at school we only focus on assessments and assignments, and sometimes seem to impose without an effective and enjoyable approach to increase the enthusiasm of students to be interested in English. So, I think the social media and the internet are important for learning English.(J_CKS-7).

The dominant use of English on social media was so meaningful and helpful for the participants to learn English, even, for those who already speak English fluently.

Social media posts in Bahasa Indonesia was usually done to respect their national language and appreciate their Indonesian followers. Social encounters, not 'academic' meetings, were done in Indonesian through social media. The original posts in Indonesian were usually chatting, personal (family) sharing, and daily communication. Besides OPs and/or followers, the main reasons of using Indonesian in their social encounters were related to language appreciation and maintenance.

media posts in Indonesian, especially when they communicated with their family members and/or their Indonesian friends.

\section{The consequence of language}

\section{preference to identity}

The participants of the study realised that English preference on social media enabled them to express to and receive from wider audience information, thoughts, feelings, and culture. They did not only talk to their parents, members of the family, classmates, and teachers; they communicated with netizens from different countries.

BEYOND WORDS Vol. 9, No.1, May 2021 Graduate School, Widya Mandala Catholic University Surabaya 
I think social media is the most influential media that can improve my As it was claimed that social media was a lifestyle did not refer to Western lifestyle but universal.

English proficiency. ... social media doesn't change a lot for me at home. I

usually use Indonesia language for communicating with my family. The most important is that I can use social media for educational media at school, or even for social community (J_ARR-130).
I always use English language on google because it always gives me a more detailed article for the information .... I rarely use English in social community because Canisius always use Bahasa Indonesia as school main language and I guess that's a good decision since Canisius is a school located in Indonesia and using Bahasa is a must for their students to keep their Indonesian identity (J_ADS-159).

Table 6.

Effects of Using English on Identity

\begin{tabular}{|c|c|c|c|c|c|c|c|c|c|c|c|c|c|c|c|c|}
\hline Identities & \multicolumn{4}{|c|}{$\begin{array}{c}\text { Indonesian } \\
\text { children }\end{array}$} & \multicolumn{4}{|c|}{ Lifestyle } & \multicolumn{4}{|c|}{$\begin{array}{l}\text { Indonesian } \\
\text { Behaviour }\end{array}$} & \multicolumn{4}{|c|}{$\begin{array}{l}\text { Western } \\
\text { behaviour }\end{array}$} \\
\hline & \multicolumn{2}{|c|}{ Agree } & \multicolumn{2}{|c|}{ Disagree } & \multicolumn{2}{|c|}{ Agree } & \multicolumn{2}{|c|}{ Disagree } & \multicolumn{2}{|c|}{ Agree } & \multicolumn{2}{|c|}{ Disagree } & \multicolumn{2}{|c|}{ Agree } & \multicolumn{2}{|c|}{ Disagree } \\
\hline Cities & $\mathrm{N}$ & $\%$ & $\mathrm{~N}$ & $\%$ & $\mathrm{~N}$ & $\%$ & $\mathrm{~N}$ & $\%$ & $\mathrm{~N}$ & $\%$ & $\mathrm{~N}$ & $\%$ & $\mathrm{~N}$ & $\%$ & $\mathrm{~N}$ & $\%$ \\
\hline Surabaya & 691 & 70 & 81 & 8 & 609 & 62 & 162 & 16 & 687 & 70 & 84 & 8 & 699 & 71 & 72 & 7 \\
\hline Jakarta & 202 & 20 & 15 & 2 & 183 & 19 & 35 & 4 & 205 & 21 & 13 & 1 & 207 & 21 & 11 & 1 \\
\hline
\end{tabular}

The participants still appreciated their being Indonesians. Posting in English on social media posts and reading social media posts in English frequently did not mean to change their identity. They did it to help them to improve their English and update or widen their views. They took English as a means of communication and acquisition of any knowledge and experiences. Although English was enhanced through social media usage, they tended not think that their national identity changed. The following opinions were written to support the use of Indonesian.

As an Indonesian, we have to be proud of our language (J_AT-48). I

Using English in daily life is very important for me. ... but I can't let my English skill makes me forget about Indonesian language. Even though I can speak, and talk English very well, my nationality is still Indonesian, and my main language is still Indonesian. But I agree and admit that English is very important these days (J_R-2).

Social media was taken as an agency inspiring the netizens to gain experiences in intercultural interaction. The relationship of language and culture on social media posts might result in one's identity. They understood that language was intrinsic to the expression of culture. For them, language and culture were intertwined; when learning English, they also learned its culture. Social media posts might affect their personal identity but not their nationality. Some of them expressed that their identity might be affected while the others thought that they expressed solidarity but kept their identity the same. 
Many of them claimed to foster their Indonesian identity.

A strong argument for fostering Indonesian identity is the following, Learning English may in fact change our identity, but it still depends on the person. Some person may get affected really fast, but some doesn't. By learning English, doesn't mean we should leave our identity. It's just a useful skill to use when speaking with foreigners. As an Indonesian, we still should respect our own language by setting our priorities straight. Using Indonesian language will be better for communicating with our Indonesian family, school, and social community (J_K-16)

\section{Discussion}

The participants of this study benefited from TV programs to enhance their English ability at home. Satellite TV programs in English which were accessible to most of the participants of the study improved their English skills. They imitated and practiced what they watched on TV programs. Subtitles on TV movies might help or not help them to understand movies in English. This finding is in line with the study of Metruk (2018) which found that watching TV with or without subtitles were not really different in listening comprehension.

Different from TV programs which strengthened printed and audio-visual literacy, social media have been introducing new literacy (Simsek \& Simsek, 2013). Through YouTube and Facebook the participants learned and practiced new literacy by blending text, sound, and imagery in their English postings. In addition to learning English as found by Amin \& Sundari (2020), they learned and practiced technology skills (Spires, Morris, \& Zhang, 2012).

The participants of the study experienced in understanding and producing social media posts in English. Social media postings which were mostly done in English enabled the participants to do productive new literacy such as text-messaging and social networking. While school environment limited itself with contact hours and academic rules, social media provided more opportunities to practice English "due to the motivating and helpful environment it provides" (Namaziandost, Branch, \& Nasri, 2019, p. 210).

YouTube introduced receptive new literacy-listening comprehension - to the participants. The participants watched and listened to YouTube to find required information for their problems and then synthesized them. Besides providing a lot of entertainment choices, YouTube was the source of English learning for the participants. Arndt \& Woore (2018) found that non-English students acquired vocabulary by reading blog posts and watching vlogs. This finding supports the findings of Moghavvemi, Sulaiman, \& Jaafar (2018) regarding YouTube as an effective tool of English learning. As sources of English learning, YouTube and the other social media platforms provided new vocabularies for the participants. This finding relates to the findings of Arndt \& Woore (2018) who found that vocabulary was acquired through reading blog posts and watching vlogs.

There was a tendency that social media was a part of the respondents' life style in a positive view. They used social media every day for socializing, learning English, and searching for new information or skills with diverse topics. Some of them even reminded users of social media not to abuse it. This finding may relate to the study of Janicke- 
bowles, Narayan, \& Seng (2018) which found that social media was a source of inspiring information.

Benefits of TV movies and social media postings were enjoyed by the participants of the study. They learned and shared authentic and communicative English. Applying the acquired authentic English of the native speakers for daily oral communication would be recommended because their English would sound natural. However, stating ideas as they are directly from the sources without credit to the author should be precautious. As argued by Li (2017), the use of social media as English learning resources should be completed with provision of referencing training by teachers.

The English learned from social media posts is different from English of the classroom. Social media postings provided up-to-date information relevant to their need in keeping friendships alive over great distances. Accordingly, English used on social media came in an environment where the participants were enjoying, learning, and picking up English in a more natural way. As argued by Darvin \& Norton (2015) and Darvin (2016), the participants of this study learned vocabularies, structures, genres and styles; indeed, they experienced new English literacy because they communicated with foreign people of different cultures. The finding of this study is in line with LantzAndersson (2018) who found that social media postings exposed casual English with diverse linguistic expressions.

English slang words were very popular in social media posts. Some participants considered them as an informal language deviating from standard English. Such English slangs did not improve their standard English. This study relates to the study of Thurairaj, Hoon, Roy, \& Fong (2015) who found that the frequent use of slangs did not affect students' English language proficiency; their essays were free from slang language.

The other participants of this study considered English slang words were cool and creative which enriched English as a living language. Although English slang words were typically restricted to a particular context or group of people, they were very common in conversation. A number of English slang words were new and not found in conventional English dictionaries. These slang words are only found in the internet and social media. This finding is in relation of Namvar \& Ibrahim (2014) who found that ESL students were very familiar with slangs on the net and social media.

The other findings of this study showed that TV movies and social media postings helped the participants to learn English and its culture. Critical thinking expressed in their short writing informed that learning English inevitably learned its culture. They learned about lifestyle and culture, and appreciated cultural differences (Jin, 2015). They appreciated the positive side of using English on social media but did not ignore the usage of Indonesian. Further, they could be categorized as being positive towards both of English and Indonesian languages and cultures. This findings is in line with the study of Rezaei \& Latifi (2019).

The participants' awareness of their national identity was revealed in this study. Learning and using English on social media posts could affect their lifestyle and their way of using English but not their Indonesian identity. This study supports the previous study of Harjanto, Lie, \& Wijaya (2019) which found that Indonesian identity was not evidently changed. Their preference of English on social media posts were navigated by their diverse needs in the digital age (Darvin \& Norton, 2015). In the same time, 
they learned to communicate in English through the Internet and learned to access any information on the Internet. Their English preference was more instrumental than integrative (Hong \& Ganapathy, 2017) which can be interpreted as one factor behind keeping their Indonesian identity.

It is too early to claim that the participants of the study were bilinguals (Lambert, 1974; Gao, 2002; Gao, Zhao, Cheng, \& Zhou 2007) in terms of Indonesian and English. Preference of English than Indonesian on TV programs and social media posts indicated they were in the process of additive change and not subtractive change (Lambert, 1974). They maintained Indonesian and their cultural identities when they acquired English and its cultures. Although little of them wrote their social media status in English they could not be called as substituting their being Indonesians by English and its culture. Inductively, the findings showed that they might undergo split changes when using social media in English but they consciously kept their being Indonesians. Further, they experienced additive change than productive change; they comprehended social media posts in English more than posted themselves in English. Overall, they seemed to be confidence in choosing English as means of communication on social media. This is in line with the study of Gao, Jia, \& Zhou (2015).

\section{Conclusion}

People on the world is now easily connected with digital media. Moreover, social media has made entertainment, information, knowledge, skills, interests, and lifestyle available. This study found that social media did not only provide social entertainment but also social networking and language learning resource. While many adults are worried with social media abuse that make millennials individualistic, the findings of this study showed that they could build and maintain relationships with their friends online. Social media has enabled them to communicate with a much larger number of people on a global scale in a way they used to do on a local level. This came to be true when they were able to use English. Realising the key role of English for global communication, the participants of this study used social media as a source of English learning. They thought that social media was an interesting English learning resource in terms of up-to-date information, considerable amount of authentic English input, interaction with native language speakers, and cutting-edge English learning.
Nevertheless, social media abuse that could sidetracked them to unscholarly and ungrammatical English and misinformation was paid attention.

Impacts on learning and using English through social media were counted as instrumental and optional. They learned English in order to use it as a means of communication. Although learning English and its culture were intertwined, knowledge of English culture complemented the participants to communicate in English properly. They still appreciated Indonesian language and behaved as Indonesians.

The findings on self-identity changes must be further verified with qualitative research approaches to uncover self-identity changes experienced by Indonesian millennials learning English. Topics about types of TV channels and social media for English learning and the use of sub-titles on TV programs and English expressions on social media are recommended for further researches. 


\section{Acknowledgments}

This article is based on a project funded by the Directorate General of Research and Development, Ministry of Research, Technology and Higher Education of the Republic of Indonesia under Grant No. 3/E/KPT/2018; 1151/WM01.5/N/2018. I am grateful to Prof. Anita Lie, Ed.D. (Widya Mandala Surabaya Catholic University) and Juliana Wijaya, Ph.D. (UCLA) for their invaluable advice in collecting and analysing the data of this study.

Dr. Ignatius Harjanto is a senior lecturer at the English Department, Widya Mandala Surabaya Catholic University, Indonesia. His research interests include discourse analysis, teacher professional development, language and identity, and language learning.

\section{References}

Abbas, J., Aman, J., Nurunnabi, M., \& Bano, S. (2019). sustainability-11-01683.pdf. Sustainability, 11(1683), 23. Retrieved from

www.mdpi.com/journal/sustainability

Abrar-ul-Hassan, S. (2010). Nativized varieties of english and the linguistic identity: A case of Indian English speakers. The Journal of Asia TEFL, 7(2), 29-68.

Akbari, E., Naderi, A., Simons, R.-J., \& Pilot, A. (2016). Student engagement and foreign language learning through online social networks. Asian-Pacific Journal of Second and Foreign Language Education, $\quad 1(1), \quad 1-22$. https://doi.org/10.1186/s40862-0160006-7

Ali, S. D., \& Hasanabbasi. (2015). Social Networks for Language Learning. Theory and Practice in Language Studies, 5(5), 1090-1095.

Alkathiri, L. A. (2019). Original Paper Students 'Perspectives towards Using Youtube in Improving EFL Learners ' Motivation to Speak. Journal of Education and Culture Studies, 3(1), 1230 . https://doi.org/10.22158/jecs.v3n1p12

Amin, F. M., \& Sundari, H. (2020). EFL Students , Preferences on Digital Platforms during Emergency Remote Teaching: Video Conference, LMS, or Messenger Application? 7(2), 362-378. Retrieved from https://doi.org/ 10.24815/ siele.v7i2.16929

Anankulladetch, P. (2017). The Impact of Social Media on ESL Students

Learning Performance (California State University). Retrieved from Digital Commons @ CSUMB\%0ACapstone Projects and Master's Theses Capstone

Anderson, B. (2006). Imagined Communities: Reflections on the Origin and Spread of Nationalism. New York: Verso.

Arndt, H. L., \& Woore, R. (2018). Vocabulary learning from watching YouTube videos and reading blog posts. Language Learning and Technology, 22(3),124-142. https://doi.org/https://doi.org/10125/446 60

Ary, D., Jacobs, L. C., \& Sorensen, C. (2010). Introduction to research in education 
(8th ed.). Belmont: Wadsworth Cengage Learning.

Benson, P. (2015). Commenting to learn: Evidence of language and intercultural learning in comments on youtube videos. Language Learning and Technology, 19(3), 88-105.

Creswell, J. W. (2014). Research Design: Qualitative, Quantitative and Mixed Methods Approaches. (4 ${ }^{\text {th }}$ ed.). Thousand Oaks, CA: Sage

Crystal, D. (2011). English as a Global Language in Chinese Context. In Theory and Practice in Language Studies (Vol. 1). https://doi.org/10.4304/tpls.1.2.167-176

Darvin, R. (2016a). Language and identity in the digital age. In M. Weinstein (Ed.), Routledge Handbook of Language and Identity (pp. 523-540). Taylor \& Francis.

Darvin, R. (2016b). Mentoring in the Digital Age. Training, 53(5), 522-540.

Darvin, R., \& Norton, B. (2015). Identity and a Model of Investment in Applied Linguistics. Annual Review of Applied Linguistics, 35, 36-56. https://doi.org/10.1017/S026719051400 0191

El-badawy, T. A., \& Hashem, Y. (2015). The Impact of Social Media on the Academic Development of School Students The Impact of Social Media on the Academic Development of School Students. (January). https://doi.org/10.5430/ijba.v6n1p46

Harjanto, I., Lie, A., \& Wijaya, J. (2019). Home, school, and community factors on Indonesian secondary students' selfidentity changes. Indonesian Journal of Applied Linguistics, 9(2), 348-358. https://doi.org/10.17509/ijal.v9i2.20232 Hong, Y. C., \& Ganapathy, M. (2017). To Investigate ESL Students 'Instrumental and Integrative Motivation towards English Language Learning in a Chinese School in Penang: Case Study. 10(9). https://doi.org/10.5539/elt.v10n9p17

Gao, Y. H. (2002). Productive bilingualism: 1+1>2. In D.W.C. So \& G.M. Jones (Eds.),

Education and society in plurilingual contexts (pp.143-162). Brussels: VUB Brussels University Press.

Gao, Y., Zhao, Y., Cheng, Y., \& Zhou, Y. (2007). Relationship between English learning motivation types and selfidentity changes among Chinese students. TESOL Quarterly, 41(1), 133-155. doi: 10.1002/j.15457249.2007.tb00043.x

Gao, Y., Jia, Z., \& Zhou, Y. (2015). EFL Learning and Identity Development: A Longitudinal Study in 5 Universities in China. Journal of Language, Identity and Education, 14(3), 137-158. https://doi.org/10.1080/15348458.2015. 1041338

Gervasio, M., \& Karuri, M. (2019). Marking Identity through Language in Social Media Discourse by Chuka University Students. International Journal on Studies in English Language and Literature (IJSELL), 7(8), 43-52.

Hou, Y., Xiong, D., Jiang, T., Song, L., \& Wang, Q. (2019). Social media addiction: Its impact, mediation, and intervention. Cyberpsychology: Journal of Psychosocial Research on Cyberspace, 13(1). Retrieved from 
https://cyberpsychology.eu/article/view/ 11562/10369

Izmaylova, A. R. (2017). Using Social Media to Develop Intercultural Competence Through Telecollaboration (University of Iowa). Retrieved from https://search.proquest.com/docview/19 31104315 ?accountid=14169

Janicke-bowles, S. H., Narayan, A., \& Seng, A. (2018). Social Media for Good? A Survey on Millennials' Inspirational Social Media Use. The Journal of Social Media in Society, 7(2), 120-140. https://doi.org/thejsms.org/tsmri/index.p $\mathrm{hp} / \mathrm{TSMRI} / \mathrm{index}$

Jin, S. (2015). Using facebook to promote korean efl learners' intercultural competence. Language Learning and Technology, 19(3), 38-51.

https://www.lltjournal.org/item/3084

Kementerian Keuangan Republik Indonesia. (2019). These are the Impacts and Opportunities of Indonesia as a MiddleIncome Country. Retrieved from Kementerian Keuangan Republik Indonesia website: www.kemenkeu. go.id

Khan, I. U., Ayaz, M., \& Faheem, M. (2016). The Role of Social Media in Development of English Language Vocabulary at University Level. International Journal of Academic Research in Business and Social Sciences, 6(11). https://doi.org/ 10.6007/ijarbss/v6-i11/2444

Kommers, P. (2011). Social Media for Learning by Means of ICT. UNESCO. 2011. (p. 12). p. 12. Retrieved from http://iite.unesco.org/files/policy_briefs/ pdf/en/social_media.pd
Lambert, W. E. (1974). Culture and Language as Factors in Learning and Education.

Lantz-Andersson, A. (2018). Language play in a second language: Social media as contexts for emerging Sociopragmatic competence. Education and Information Technologies, 23(2), 705-724. https://doi.org/10.1007/s10639-0179631-0

Li, V. (2017). Social Media in English Language Teaching and Learning. (June). https://doi.org/10.18178/ijlt.3.2. 148-153

Lie, A., Wijaya, J., \& Kuntjara, E. (2018). Linguistic and cultural identity of Indonesian Americans in The United States. Indonesian Journal of Applied Linguistics, 8(1), 198-207. https://doi.org/10.17509/ijal.v8i1.11468

Lightbown, P. and Spada, N. (2006). How languages are learned (3rd ed). Oxford: Oxford University Press.

Metruk, R. (2018). The Effects of Watching Authentic English Videos with and without Subtitles on Listening and Reading Skills of EFL Learners. EURASIA Journal of Mathematics, Science and Technology Education, 14(6), 2545-2553. https://doi.org/ doi.org/10.29333/ejmste/90088

Moghavvemi, S., Sulaiman, A., \& Jaafar, N. I. (2018). The International Journal of Social media as a complementary learning tool for teaching and learning : The case of youtube. 16(November 2017), 37-42. https://doi.org/10.1016 /j.ijme.2017.12.001

Murray, D. E., \& Christison, M. (2019). What English Language Teachers Need 
to Know Volume I. In What English Language Teachers Need to Know Vol I. https://doi.org/10.4324/9781351139847

Namaziandost, E., Branch, S., \& Nasri, M. (2019). The Impact of Social Media on EFL Learners' Speaking Skill: A Survey Study Involving EFL Teachers and Students. Journal of Applied Linguistics and Language Research, 6(January), 199-215. Retrieved from http://www.jallr.com/index.php/JALLR/ article/view/1031/pdf1031

Namvar, F., \& Ibrahim, N. (2014). Popularity and Familiarity of Slang among ESL Students. Journal of Applied Sciences, 14(24),3585-3590. https://doi.org/ 10.3923/jas. 2014.3585.3590

Norton, B. (1995). Social Identity, Investment, and Language Learning. TESOL Qurterly, 29(1), 9-31. https://doi.org/10.2307/3587803

Norton, B. (2013). Identity and Language Learning: Extending the Conversation Second edition. Bristol: Multilingual Matters.

Norton, B., \& Toohey, K. (2011). Identity, language learning, and social change. Language Teaching, 44(4), 412-446. https://doi.org/10.1017/S026144481100 0309

Pavlenko, A. and Lantolf, J.P. (2000) Second language learning as participation and the (re)construction of selves. In Lantolf, JP (ed), Sociocultural theory and second language learning (pp. 155-177). Oxford: Oxford University Press.

Rassokha, M. (2010). Language Identity: Issues of Theory and Practice. Asian Englishes, 13(1), 20-33.https://doi.org/ 10.1080/ 13488678.2010.10801270
Rezaei, S., \& Latifi, A. (2019). Iranian EFL learners' identity construction in a critical reflective course: a case of an online course. Open Learning, 00(00), 1-19. ttps://doi.org/10.1080/02680513. 2019.1632700

Sa'd, S. H. T. (2017). Foreign Language Learning and Identity Reconstruction: Learners' Understanding of the Intersections of the Self, the Other and Power. Center for Educational Policy Studies Journal, 7(4), 13-36.

Schreiber, B. R. (2015). "I am What I am": Multilingual Identity and Digital Translannguaing. Language Learning \& Technology, 19(3), 69-87.

Simsek, E., \& Simsek, A. (2013). New Literacies for Digital Citizenship. Contemporary Educational Technology, 4(2), 126-137.

Spires, H. A., Morris, G., \& Zhang, J. (2012). New Literacies and Emerging Technologies: Perspectives from U.S. and Chinese Middle Level Teachers. RMLE Online, 35(10), 1-11. https://doi.org/10.1080/19404476.2012. 11462093

Stuart-Smith, J., Timmins, C., Pryce, G., \& Gunter, B. (2013). Television canalso beafactor in language change: Evidence froman urban dialect. Language, 89(3), 501-536.

https://doi.org/10.1353/lan.2013.0041

Thurairaj, S., Hoon, E. P., Roy, S. S., \& Fong, P. W. (2015). Reflections of students' language usage in social networking sites: Making or marring academic English. The Electronic Journal of ELearning, 13(4), 302-316. 
Turnbull, B. (2017). Learner Perspectives on National Identity and EFL Education in Japan : Report of a Questionnaire Study. The Journal of AsiaTEFL, 14(2), 211227. https://doi.org/10.18823/asiatefl. 2017.14.2.1.211

Wenger, E. (2010). Communities of practice and social learning systems: The career of a concept. Social Learning Systems and Communities of Practice, 179-198. https://doi.org/10.1007/978-1-84996133-2_11

Yazan, B., Rudolph, N., \& Selvi, A. F. (2019). Borderland negotiations of identity in language education: Introducing the special issue. International Multilingual Research Journal, 13(3), 133-136. https://doi.org/ 10.1080/ 19313152.2019.1633095
Zhao, S., Grasmuck, S., \& Martin, J. (2008). Identity construction on Facebook: Digital empowerment in anchored relationships. Computers in Human Behavior. https://doi.org/10.1016/j.chb. 2008.02.012

Zhou, W., \& Zhou, M. (2018). Role of SelfIdentity and Self-Determination in English Learning among High School Students. Journal of Language, Identity and Education, 17(3), 168-181. https://doi.org/10.1080/15348458.2018. 1433537 